\title{
Maturity-onset diabetes of the young (MODY): Recognition is the need of the hour
}

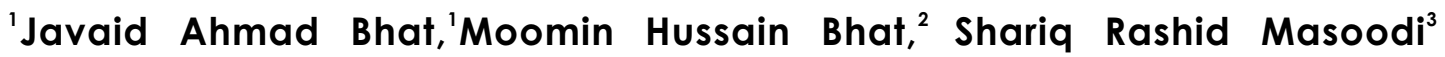 \\ 'Department of Endocrinology, GMC, Srinagar, ${ }^{2,3}$ Department of Endocrinology, SKIMS
}

\section{A B S T R A C T}

\begin{abstract}
Maturity-onset diabetes of the young (MODY), which is inherited as an autosomal dominant disease, is a monogenic form of diabetes with earlyonset diabetes, and mostly mild hyperglycemia resulting from pancreatic $\beta$-cell dysfunction. MODY gets commonly misdiagnosed as type 1 or type 2 diabetes mellitus, which represents less than $2 \%$ of all diabetes cases. It is a genetically heterogeneous form of monogenic diabetes that is caused by mutations occurring in different genes thus tends to cause a slightly different variant of diabetes. At least 14 MODY subtypes with distinct genetic etiologies have been identified. Typically, MODY is diagnosed during late childhood, adolescence, or early adulthood but can occasionally develop in adults during their late 50's. One of the main drawbacks of diagnosing MODY is that many people are misdiagnosed as having type 1or type 2 diabetes due to a low index of suspicion and non-availability of genetic testing at an affordable cost. Nonetheless, a molecular and genetic diagnosis results in better treatment and could also help in identifying other family members with MODY. Misdiagnosing MODY as type 1 diabetes may have a significant impact on the quality of life (QOL) with increased cost and unnecessary treatment with insulin, and therefore a high index of suspicion is required to diagnose cases.

Keywords: Maturity Onset Diabetes of Young (MODY), gene mutation, monogenic diabetes.

JMS: 2019; 22(2):3-11 DOI:https://doi.org/10.33883/jms.v22i2.486
\end{abstract}

\section{INTRODUCTION}

Diabetes mellitus (DM) is a chronic metabolic disorder with widespread implications on the social, economic, and health status of an individual. It is fast emerging as a global epidemic affecting almost all the countries irrespective of the socioeconomic conditions. Apart from micro and macro-vascular complications, diabetes mellitus patients are at risk of specific fatal infections ${ }^{1}$. According to the International Diabetes Federation estimates, around 425 million people had DM in 2017, and this number is expected to rise to 629 million by $2045^{2}$. As per the estimate, $75 \%$ of patients with diabetes live in middle and low-income countries $^{3}$. Type 2 diabetes (T2DM) is the most common type of this disorder followed by type 1 diabetes (T1DM), both of which account for more than $95 \%$ of cases. Less frequent causes include pancreatic diabetes, monogenic diabetes, and other secondary forms of DM. Maturity onset diabetes of the youth (MODY) is characterised by

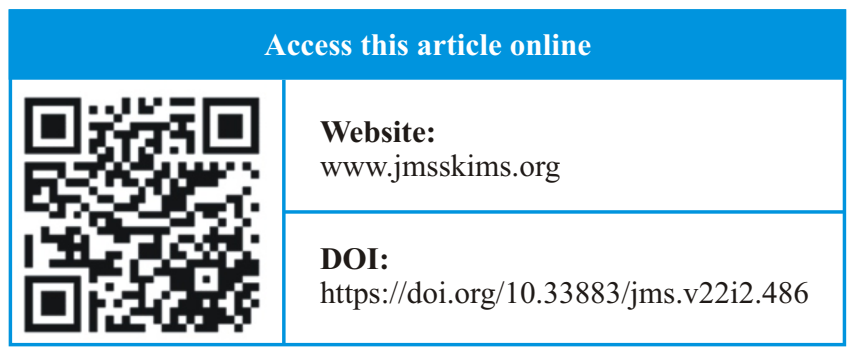

autosomal dominant inheritance affecting three or more successive generation, early onset of diabetes, lack of features of insulin resistance or signs related to the autoimmune process, preservation of endogenous insulin secretion $^{4,5}$ and mild hyperglycemia in some forms and better prognosis. The symptoms of this disease manifest slowly with the absence of obesity and ketosis in most cases.

MODY is the result of heterozygous mutations in various transcription factors. These mutations involve genes coding for transcription factors involved in beta cell development, differentiation, and survival ${ }^{6}$ in addition to enzymes involved in glucose sensing of the pancreatic $\beta$-cell resulting in a unique form of early-onset diabetes?

Correspondence:

Dr. Shariq R Masoodi, DM

Room 1331, 3rd Floor,

Department of Endocrinology, SKIMS, Srinagar

e-mail: shariq.masoodi@gmail.com

How to cite this article: Bhat JA, Bhat MH, Masoodi SR. Maturity-onset diabetes of the young (MODY): Recognition is the need of the hour. jms 2019;22(2):3-11

Received: 30-11-2019 Accepted:04-12-2019 
Bhat JA; et al; Maturity-onset diabetes of the young (MODY): Recognition is the need of the hour

\section{Historical aspects}

Maturity Onset Diabetes of the Young was first described by Fajans and Conn ${ }^{8}$, who first reported youth onset diabetic patients who were not dependent on insulin. Later Tattersall (1974) from King's College, London, published a report entitled "Mild familial diabetes with dominant inheritance," where he described three families with an autosomal dominant form of diabetes. This form of diabetes had early onset, mild hyperglycemia, and relatively uncomplicated course. In these families, they found that seven out of 12 diabetes patients diagnosed under the age of 30 had no retinopathy after an average duration of 37 years. In these two families studied, diabetes was associated with a low renal threshold for glucose. They noted an autosomal dominant pattern of the disease in these families in addition to evidence of the genetic heterogeneity of diabetes mellitus 9 .

Further evidence for a separate autosomal dominant form was provided by Tattersall and Fajans (1975) and by Johansen and Gregersen (1977) ${ }^{10,11}$. The term MODY was first used by Tattersall and Fajans, who used first letters of the new entity in diabetes called Maturity onset diabetes of young, in their paper titled " A difference between the inheritance of classical juvenile-onset and maturity-onset type diabetes of young people." They also laid down the criteria for the diagnosis of MODY ${ }^{12}$. Nelson and Pyke (1976) referred to this as maturity-onset diabetes of the young while describing three families with this different kind of diabetes ${ }^{13}$. It has also been called the Mason type, after the family in which it was first observed ${ }^{14}$.

\section{Prevalence}

MODY is the commonest form of monogenic form of diabetes. MODY represents $1-2 \%$ of patients diagnosed with diabetes and accounts for less than $1 \%-2.4 \%$ of the pediatric diabetes population (1517). Recent studies have reported a MODY prevalence of 21-45/1,000,000 children and 100/1,000,000 adults (1920), but prevalence estimates will not be accurate until large population screening studies are performed $^{21}$.

The prevalence of MODY in different populations is still unknown. A study by Panzram, done almost five decades back, is the only study that examined the prevalence of MODY in the general population and found it to be $0.15 \%$. In southern India prevalence of MODY was estimated to be
$4.8 \%$ among patients of non-insulin dependent diabetes mellitus (NIDDM) who had age at diagnosis below 25 years, $18.5 \%$ below 35 years and almost 50\% below 45 years $^{23}$,suggesting a higher prevalence of MODY among Indian patients.

It has been reported that MODY is not a common form of diabetes among the white population ${ }^{22}$. However, a number of reports from Europe and the United States have confirmed the existence of MODY ${ }^{22,24-27}$. The prevalence of MODY is higher than previously thought in certain communities of the world. The higher rates of prevalence ranging from $4.8 \%-10 \%$ have been shown in studies involving Pima Indians, Nauru population, and also in Asian Indians in South Africa and southern India ${ }^{22-23,27-28}$. A study was conducted in Kashmir valley to determine the prevalence of MODY among diabetic patients aged $<25$ years of ageand found a prevalence of $7.7 \%$, with an increase in prevalence with increasing age in the disease onset in the patient cohort. Forty patients of clinically identified MODY were subjected to the amino acid polymorphism (SNP) of Ala $>$ Val on codon 98 in the HNF $1 \alpha$ gene (MODY 3), the mutant genotype was seen in $50 \%$ of patients (unpublished).

\section{Genetic classification and clinical types of MODY subtypes}

There is wide clinical, metabolic, and genetic heterogeneity within and among the different subtypes of MODY. So far, 14 types of mutations responsible for the same number of MODY types have been elucidated (Table 1). Novel MODY-causing genes are still being defined, and their roles in the pathogenesis of diabetes are being investigated ${ }^{29}$. It is believed that many MODY-related genes have not yet been identified (30).

The first MODY gene to be documented was glucokinase $(\mathrm{GCK})^{31-32}$, followed by hepatocyte nuclear factors- HNF $1 \alpha$ (TCF1) and HNF4 $\alpha^{33,34}$. They encode glucokinase and transcription factors that are responsible for the early processing of glucose in the $\beta$-cell, thus acting as a glucose sensor for beta cells and transcription factors that modulate the expression of numerous genes concerned with the growth, proliferation, and differentiation of $\beta$-cells respectively. In a study by Shields et al, over $99 \%$ of MODY with a known genetic etiology results from mutations in HNF1 $\alpha, \mathrm{HNF} 4 \alpha$, or $\mathrm{GCK}^{18}$. Although mutations in other genes have been shown to cause MODY ${ }^{8}$, they are very rare. 
Bhat JA; et al; Maturity-onset diabetes of the young (MODY): Recognition is the need of the hour

\section{Specific subtypes and their properties}

\section{GCK -MODY (MODY2)}

The conversion of glucose to glucose-6-phosphate inside the pancreatic $\beta$-cell is catalysed by a glycolytic enzymeglucokinase (GCK), which is also referred to as the $\beta$-cell glucose sensor because it controls glucose-mediated insulin release. Heterozygous inactivating mutations of this enzyme (GCK) cause GCK-MODY, which is also known as MODY2. This entity was first recognized in $1992^{31}$.

\section{HNF1 $2-M O D Y(M O D Y 3)$}

Heterozygous mutation in the transcription factor HNF1 $\alpha$ result in progressive $\beta$-cell dysfunction and leads to diabetes in early adult life. A high penetrance is demonstrated by these mutations; by 25 years of age, almost $63 \%$ of carriers develop diabetes, and almost all carriers develop diabetes by the age of $55^{35}$. The mean age of MODY3 diagnosis in children is 14 years (range 4-18 years) and is rarely identified in children younger than ten years ${ }^{36}$.

\section{HNF4 $\alpha-M O D Y$ (MODY1)}

The transcription factor HNF4ais expressed mainly in the liver in addition to pancreatic islets and kidneys, and affects glucose metabolism, which results in hyperglycemia. The clinical profile of heterozygous HNF $4 \alpha$ mutations is similar to HNF1 $\alpha$ MODY. Patients with MODY1 diabetes are never diagnosed before adolescence.

\section{PDX1-MODY (MODY4)}

PDX1 homeodomain-containing transcription factor, described first in 1997, is a very rare cause of MODY ${ }^{37}$. Permanent neonatal diabetes is caused by homozygous mutations ${ }^{38}$, while heterozygous mutations lead to $\beta$-cell dysfunction and MODY ${ }^{37}$.

\section{HNF1及 -MODY (MODY5)}

HNF1Bis expressed in the early phase of embryonic development in the pancreas, kidneys, liver, and genital tract. Developmental abnormalities may, therefore, be encountered in all of these organs in individuals with HNF1及 mutations. MODY5 is characterized by progressive non-diabetic renal dysfunction of variable severity, pancreatic atrophy, genital abnormalities, gallbladder dysfunction, gout, and hyperuricemia ${ }^{39-41}$. RCAD (renal cysts and diabetes syndrome) is another name

\section{for MODY5.}

\section{NEUROD1-MODY (MODY6)}

NEUROD1 gene regulates the development of the pancreas and INS expression. The majority of the patients with this mutation are obese. Heterozygous NEUROD1 mutations lead to diabetes inchildren and adults, while homozygous mutations result in neonatal diabetes with neurological abnormalities, vision, hearing, and learning disabilities ${ }^{42-44}$.

\section{CEL-MODY (MODY8)}

CEL, also called bile salt-stimulated lipase, is expressed in mammary glands and pancreatic acinar cells, is a major component of pancreatic juice, and is responsible for the hydrolysis of cholesterol esters as well as a variety of other dietary esters. In a study by Johansson et al, it was observed that patients with heterozygous mutations of CEL had exocrine pancreatic dysfunction during childhood and diabetes mellitus in adulthood. Also, it was found that these patients had pancreatic atrophy, fibrosis, and lipomatosis on histopathology ${ }^{45}$.

\section{ABCC8-MODY (MODY12)}

The ABCC8 gene is located on chromosome 12. It encodes the sulfonylurea receptor 1 (SUR1) subunit of ATPsensitive potassium channel on pancreatic $\beta$ cells. Activating mutation of ABCC8 (homozygous or heterozygous) causes neonatal diabetes; however, heterozygous mutations of this gene also cause MODY, which is similar to HNF1A/4A MODY ${ }^{46}$. It is important to diagnose these patients correctly, as these patients are very sensitive to sulfonylureas.

\section{KCNJ11-MODY (MODY13)}

The KCNJ11 gene encodes Kir6.2, a part of the ATPsensitive potassium channel. It's activating homozygous mutations cause neonatal diabetes, but heterozygous mutations have been associated with MODY13. MODY13 is diagnosed from childhood to adulthood (13 to 59 years), and the treatment varied from diet to OAD or insulin ${ }^{47}$.

Other than the types of MODY described above, there are a number of very rarer forms that have been described, but their contribution to the burden of diabetes is almost negligible. These rarer forms include MODY7 (KLF11), MODY9 (PAX4), MODY10 (INS), MODY11 (BLK), and MODY14(WFS). 
Bhat JA; et al; Maturity-onset diabetes of the young (MODY): Recognition is the need of the hour

Table 1. Genetic classification and clinical phenotypes and treatment of the MODY subtypes.

\begin{tabular}{|c|c|c|c|c|}
\hline MODY & Gene & Locus & Clinical features & Treatment \\
\hline MODY1 & $\begin{array}{l}\text { Hepatocyte nuclear } \\
\text { factor } 4 \alpha(\mathrm{HNF} 4 \mathrm{~A})\end{array}$ & $20 q 12-q 13.1$ & $\begin{array}{l}\text { Mild-severe fasting and postprandial } \\
\text { plasma glucose (PG). Progressive insulin } \\
\text { secretory defect. Fetal macrosomia, } \\
\text { transient neonatal hypoglycemia }\end{array}$ & $\begin{array}{l}\text { Respond well to } \\
\text { sulphonylurea agents }\end{array}$ \\
\hline MODY2 & Glucokinase(GCK) & $7 \mathrm{p} 15-\mathrm{p} 13$ & $\begin{array}{l}\text { Mild fasting hyperglycemia. } \\
\text { Asymptomatic/abnormal OGTT/ GDM } \\
\text { /LBW. Less than } 50 \% \text { of carriers have } \\
\text { overt diabetes and microvascular } \\
\text { complications of diabetes are rare }\end{array}$ & $\begin{array}{l}\text { Treatment not needed } \\
\text { except in pregnancy. }\end{array}$ \\
\hline MODY3 & $\begin{array}{l}\text { Hepatocyte nuclear } \\
\text { factor } 1 \alpha(\mathrm{HNF} 1-\mathrm{A})\end{array}$ & $12 \mathrm{q} 24.2$ & $\begin{array}{l}\text { The most common type of MODY. } \\
\text { Familial, early-onset diabetes and renal } \\
\text { glycosuria }\end{array}$ & $\begin{array}{l}\text { Typically insulin is not } \\
\text { immediately required. } \\
\text { Often } \\
\text { responds well to } \\
\text { sulfonylurea pills }\end{array}$ \\
\hline MODY4 & $\begin{array}{l}\text { Insulin promoter } \\
\text { factor-1 } \\
\text { (IPF-1/PDX) }\end{array}$ & $13 \mathrm{q} 12.1$ & $\begin{array}{l}\text { Very rare, mild diabetes (in the } \\
\text { heterozygous form), Pancreatic agenesis in } \\
\text { homozygous form }\end{array}$ & Diet or OAD or insulin \\
\hline MODY5 & $\begin{array}{l}\text { Hepatocyte nuclear } \\
\text { factor } 1 \beta(\mathrm{HNF} 1-\mathrm{B})\end{array}$ & 17 cen-q21.3 & $\begin{array}{l}\text { Overt diabetes in association with renal } \\
\text { (RCAD), genitourinary abnormalities, } \\
\text { pancreatic atrophy, exocrine dysfunction, } \\
\text { hyperuricemia }\end{array}$ & Insulin \\
\hline MODY6 & $\begin{array}{l}\text { Neurogenic } \\
\text { differentiation } 1 \\
\text { (NEUROD1) } \\
\end{array}$ & $2 q 32$ & $\begin{array}{l}\text { Rare; the phenotype is characterized by } \\
\text { obesity and insulin resistance. }\end{array}$ & OAD or insulin \\
\hline MODY7 & $\begin{array}{l}\text { Kruppel-like factor } \\
11 \text { (KLF11) }\end{array}$ & $2 \mathrm{P} 25$ & $\begin{array}{l}\text { Very rare, phenotype varies in glucose } \\
\text { tolerance, from impaired glucose tolerance } \\
\text { or impaired fasting glucose to overt } \\
\text { diabetes. Pancreatic atrophy, exocrine } \\
\text { pancreatic dysfunction }\end{array}$ & OAD or insulin \\
\hline MODY8 & $\begin{array}{l}\text { Bile salt-dependent } \\
\text { lipase (CELL) }\end{array}$ & $9 q 34.3$ & $\begin{array}{l}\text { Very rare; characterised by both exocrine } \\
\text { and endocrine pancreatic deficiency with } \\
\text { demyelinating peripheral neuropathy and } \\
\text { lipomatosis }\end{array}$ & OAD or insulin \\
\hline MODY9 & $\begin{array}{l}\text { Paired Domain gene } \\
4 \\
(\mathrm{PAX} 4)\end{array}$ & $7 \mathrm{q} 32$ & $\begin{array}{l}\text { Very rare. Crucial transcription factor for } \\
\text { beta cells development }\end{array}$ & Diet or OAD or insulin \\
\hline MODY10 & Insulin (INS) & $11 \mathrm{p} 15.5$ & $\begin{array}{l}\text { Very rare. Usually associated with } \\
\text { neonatal diabetes. }<1 \% \text { cases. }\end{array}$ & OAD or insulin \\
\hline MODY11 & $\begin{array}{l}\text { Tyrosine kinase, } \\
\text { B-Lymphocyte } \\
\text { specific (BLK) }\end{array}$ & $8 \mathrm{p} 23-\mathrm{p} 22$ & $\begin{array}{l}\text { These adapter proteins' nucleate formation } \\
\text { contributes to the qualitative and } \\
\text { quantitative control of beta-cell signaling. }\end{array}$ & Diet or OAD or insulin \\
\hline MODY12 & ABCC8 & $11 \mathrm{p} 15.1$ & $\begin{array}{l}\text { Very rare. Usually associated with } \\
\text { neonatal diabetes. }<1 \% \text { cases. }\end{array}$ & OAD (sulfonylurea) \\
\hline MODY13 & KCNJ11 & $11 \mathrm{p} 15.1$ & $\begin{array}{l}\text { Very rare. Usually associated with } \\
\text { neonatal diabetes. }<1 \% \text { cases. }\end{array}$ & Diet or OAD or insulin \\
\hline MODY14 & WFS & $4 \mathrm{p} 16.1$ & $\begin{array}{l}\text { Rare. Usually associated with DIDMOAD } \\
\text { syndrome. Also, seen with early-onset } \\
\text { diabetes. }<1 \% \text { cases. }\end{array}$ & Diet or OAD or insulin \\
\hline
\end{tabular}

MODY: Maturity-onset diabetes of the young, GCK: Glucokinase, CEL: Carboxy ester lipase,

RCAD: Renal cyst and diabetes, OAD: Oral antidiabetic drug. 
Bhat JA; et al; Maturity-onset diabetes of the young (MODY): Recognition is the need of the hour

\section{Diagnosis}

The accurate diagnosis of MODY has not only the clinical implication in the treatment modalities and cost of the management of disease but also the socioeconomic outlook of the disease besides having a definite out bearing on the clinical outcome and course of the disease. The clinical implications of an accurate MODY diagnosis include: i) treatment modality, ii) determination of the natural progression of MODY, iii) familial screening, iv) management of MODY during pregnancy, and v) MODY as a model for the study of the $\beta$-cell.

Typically MODY is diagnosed during late childhood, adolescence, or early adulthood but has been known to develop in adults as old as 50 years. It has been determined that $5 \%$ of individuals diagnosed with diabetes before the age of 45 years have MODY, with $80 \%$ of individuals misdiagnosed as having type 1 or type 2 diabetes mellitus ${ }^{18}$ thus the most under-diagnosed condition. MODY must be distinguished from type 1 and type 2 diabetes as optimal treatment and inheritanceis different. Furthermore, the probability of inheriting the same mutation is $50 \%$ among the first degree relatives, which confers a greater than $95 \%$ lifetime risk of developing diabetes ${ }^{48}$.

The clinical diagnosis of MODY laid down by Tattersall and Fajans ${ }^{10}$ is usually based on the following criteria: i) age at diagnosis below 25 years, ii) control of fasting hyperglycemia without insulin for a minimum of 2 years, and iii) absence of ketosis at any time. Later, Tattersall suggested to extend the period, without insulin, to 5 years, to completely exclude insulin-dependent diabetes mellitus (IDDM) patients, who might initially respond to oral agents. It has also been suggested that autosomal dominant inheritance should be used as a diagnostic criterion.

MODY is particularly suspected in individuals meeting these criteria who are lean and not from ethnic groups with a high prevalence of type 2 diabetes (e.g., African American, Hispanic, and Pacific Islander). Lack of these type 2 diabetes risk factors and type 1-diabetes specific markers including diabetes auto-antibodies and low C-peptide (as a measure of endogenous insulin production) can be evaluated to differentiate the probability of MODY from early-stage type 1 diabetes and type 2 diabetes, but these risk factors including adiposity do not completely differentiate the diagnoses. So clinical definition for diagnosis is no longer sufficient to make the diagnosis, but it should be supplemented with genetic testing to confirm, diagnose, and classify MODY. According to the International Society for Pediatric \& Adolescent Diabetes (ISPAD), a diagnosis of monogenic diabetes cannot be made now without genetic testing ${ }^{49}$.

The field of genetics is rapidly advancing due to decreasing costs and increasing the capabilities of next-generation sequencing (NGS). By direct sequencing, MODY can now be diagnosed with up to $100 \%$ sensitivity (50). MODY gene mutations can be successfully identified by next-generation sequencing strategies using gene-targeted and wholeexome sequencing ${ }^{29,51}$. However, molecular genetic testing is still expensive and is only available in specialized laboratories.

In limited-resource countries, a targeted selection of patients for molecular genetic testing is necessary to improve diagnostic yields. Various clinical and laboratory parametershave been proposed in different algorithms to choose correct candidates for molecular diagnosis ${ }^{52,53}$. A model developed by Shields et al. ${ }^{53}$ found that age at diagnosis below 30 years was the most useful discriminator between MODY and T2DM. They also found that a family history of diabetes increased the probability of MODY diagnosis by 23 times in those who had been initially labeled as T1DM. This model determines the probability of MODY in young-onset diabetes (http://www.diabetesgenes.org/ content/mody-probability-calcualtor).

In recent years, researchers have attempted to identify inexpensive and widely available biomarkers that are sensitive and specific for identifying persons with MODY. C-reactive protein (CRP) has exhibited the most promise for identifying HNF1 $\alpha$-MODY but no other MODY subtypes $^{54,55}$. Since HNF1- $\alpha$ is a regulator of fucosylation of proteins, the examination of plasma glycoprotein profiles can indicate $H N F 1 A$ damaging variants ${ }^{56}$. A major downside of this metabolite marker is that there is no high-throughput technique for this measure. Other metabolites, including CD36, cystatin C, and ghrelin, have also been studied for the same purpose, but to less extent than CRP or glycoprotein profiles $^{57}$.

\section{Treatment}

The treatment of individuals with MODY2 (GCK MODY) is not recommended because hyperglycemia is mild, and 
Bhat JA; et al; Maturity-onset diabetes of the young (MODY): Recognition is the need of the hour

microvascular complications are not encountered ${ }^{7,58}$. In addition, no change is observed in HbAlc values after discontinuing treatment with insulin or oral hypoglycemic agents $^{42,59}$. The exception is pregnant women, in whom insulin may be required to prevent fetal overgrowth and subsequent maternal and fetal complications associated with macrosomia.

Sulfonylureas have been found to be the treatment of choice in the case of individuals with MODY3 and MODY1. A low-dose sulfonylurea (e.g., $20-40 \mathrm{mg} /$ day gliclazide) is the preferred long-term treatment. It has also been reported that gliclazide improved fasting blood glucose levels by 5.2 -fold compared with ${ }^{60}$. Similar sulphonylurea efficacy has been described in MODY3/MODY1 patients ${ }^{61}$, with the exception of a small (about 15\%) subgroup of HNF4- $\alpha$ MODY patients with the p.R114W mutation who have different phenotype including reduced sensitivity to low doses of sulphonylureas ${ }^{62}$. The optimal treatment for MODY3/MODY1 outside pregnancy is Sulphonylureas and glibenclamide.

In general, patients with MODY3 develop sulfonylurea unresponsiveness after 3-25 years due to the progressive decrease in insulin secretion (1-4\% decrease each year) and become insulin-dependent in adulthood ${ }^{63}$. A similar response to sulfonylureas has been reported in patients with MODY $1^{64}$. Patients with MODY5 do not generally respond to sulfonylureas and typically require insulin early on in their disease. Moreover, these patients have been reported to develop microvascular complications ${ }^{65}$.

Conclusion MODY is a rarer form of diabetes; however, its presence has been reported from across the world. Being a highly penetrant genetic form of diabetes, its presence needs to be recognized accurately in order to provide appropriate treatment. A high index of suspicion is required to diagnose cases of MODY as misdiagnosis, and inappropriate treatment may have a significant impact on the quality of life (QOL) with increased cost and unnecessary treatment with insulin. Since etiology-specific treatment of MODY can have a drastic improvement in patient care, the implementation of genetic testing needs to be emphasized and made available everywhere. While improving MODY diagnosis will certainly improve the clinical care for patients, it will also have broader implications.

\section{REFERENCES}

1. Sood M, Bhat F, Masoodi S, Sofi F, Rahman Y, Bhat M, Wani A, Bashir M, Ganie M, Zargar AH. Comparative Analysis of Spectrum and Outcome of Common bacterial Infections in Patients with and without Diabetes-a Prospective Hospital Based Study.Journal of Medical Sciences 2018;21(2):84-90.

2. Available from: http://www.diabetesatlas.org/acrossthe-globe.html.

3. Ogurtsova K, Fernandes JD da R, Huang Y, Linnenkamp U, Guariguata L, Cho NH, et al. IDF Diabetes Atlas: Global estimates for the prevalence of diabetes for 2015 and 2040. Diabetes Res ClinPract 2017;128:4050.

4. McDonald TJ, Colclough K, Brown R, Shields B, Shepherd M, et al. Islet autoantibodies can discriminate maturity-onset diabetes of the young (MODY) from Type 1 diabetes. Diabet Med 2011;28:102833.

5. Owen KR, Roland J, Smith K, Hattersley AT. Adolescent onset Type 2 diabetes in a non-obese Caucasian patient with an unbalanced translocation.Diabet Med 2003;20:4835.

6. Fajans SS, Bell GI. MODY: history, genetics, pathophysiology, and clinical decision making. Diabetes Care 2011;34:187884.

7. Osbak KK, Colclough K, Saint-Martin C, Beer NL, Bellanne-Chantelot $\mathrm{C}$, et al. Update on mutations in glucokinase (GCK), which cause maturity-onset diabetes of the young, permanent neonatal diabetes, and hyperinsulinemic hypoglycemia. Hum Mutat 2009;30:151226.

8. Fajans SS, Conn JW. Prediabetes, subclinical diabetes and latent clinical diabetes: interpretation, diagnosis and treatment. Nat Treat Diabetes 1965;641656.

9. Tattersall RB. Mild familial diabetes with dominant inheritance. Q J Med 1974;43:33957.

10. Tattersall RB, Fajans SS. A difference between the inheritance of classical juvenile-onset and maturityonset type diabetes of young people. Diabetes $1975 ; 24: 4453$.

11. Johansen K, Gregersen G. A family with dominantly inherited mild juvenile diabetes.Acta Med Scand 1977;201:56770. 
Bhat JA; et al; Maturity-onset diabetes of the young (MODY): Recognition is the need of the hour

12. Tattersall RB, Fajans SS. A difference between the inheritance of classical juvenile-onset and maturityonset type diabetes of young people. Diabetes $1975 ; 24: 4453$.

13. Nelson PG, Pyke DA. Genetic diabetes not linked to the HLA locus. Br Med J 1976;24;1:1967.

14. Johnston C, Owerbach D, Leslie RDG, Pyke DA, Nerup J. Mason-type diabetes and DNA insertion polymorphism. The Lancet 1984;323:280.

15. Galler A, Stange T, Müller G, Näke A, Vogel C, Kapellen T, et al. Incidence of childhood diabetes in children aged less than 15 years and its clinical and metabolic characteristics at the time of diagnosis: data from the Childhood Diabetes Registry of Saxony, Germany. Horm Res Paediatr 2010;74:28591.

16. Neu A, Feldhahn L, Ehehalt S, Hub R, Ranke MB, DIARY group Baden-Württemberg. Type 2 diabetes mellitus in children and adolescents is still a rare disease in Germany: a population-based assessment of the prevalence of type 2 diabetes and MODY in patients aged 0-20 years. Pediatr Diabetes 2009;10:46873.

17. Schober E, Rami B, Grabert M, Thon A, Kapellen T, Reinehr T, et al. Phenotypical aspects of maturity-onset diabetes of the young (MODY diabetes) in comparison with Type 2 diabetes mellitus (T2DM) in children and adolescents: experience from a large multicentre database. Diabet Med J Br DiabetAssoc 2009;26:46673.

18. Shields BM, Hicks S, Shepherd MH, Colclough K, Hattersley AT, et al. Maturity-onset diabetes of the young (MODY): how many cases are we missing? Diabetologia 2010;53:25048.

19. Kropff J, Selwood MP, McCarthy MI, Farmer AJ, Owen KR. Prevalence of monogenic diabetes in young adults: a community based, cross-sectional study in Oxfordshire, UK. Diabetologia 2011;54:12613.

20. Pihoker C, Gilliam LK, Ellard S, Dabelea D, Davis C, Dolan LM, et al. Prevalence, characteristics and clinical diagnosis of maturity onset diabetes of the young due to mutations in HNF1A, HNF4A, and glucokinase: results from the SEARCH for Diabetes in Youth. J ClinEndocrinolMetab 2013;98:405562.

21. Ledermann HM. Is maturity onset diabetes at young age (MODY) more common in Europe than previously assumed? Lancet LondEngl 1995;345(8950):648.

22. Panzram G, Adolph W. Heterogeneity of maturity onset diabetes at young age (MODY). Lancet LondEngl 1981;2:986.

23. Mohan V, Ramachandran A, Snehalatha C, Mohan R, Bharani G, Viswanathan M. High prevalence of maturity-onset diabetes of the young (MODY) among Indians. Diabetes Care 1985;8:3714.

24. Johansen K. Mild diabetes in young subjects. Clinical aspects and plasma insulin response pattern.Acta Med Scand 1973;193:2333.

25. Barbosa J, Ramsay R, Goetz FC. Plasma glucose, insulin, glucagon, and growth hormone in kindreds with maturity-onset type of hyperglycemia in young people. Ann Intern Med 1978;88:595601.

26. Faber OK, Thomsen M, Binder C, Platz P, Svejgaard A. HLA antigens in a family with maturity-onset type diabetes mellitus. ActaEndocrinol (Copenh) 1978;88:32938.

27. Serjeantson S, Zimmet P. Diabetes in the Pacific: evidence for a major gene. Diabetes Mellit Recent KnowlAetiolComplicat Treat 1984;2330.

28. Asmal AC, Dayal B, Jialal I, Leary WP, Omar MA, Pillay NL, et al. Non-insulin-dependent diabetes mellitus with early onset in Blacks and Indians. South African Medical Journal SuidAfrikaanseTydskrifVirGeneeskunde. 1981;60:936.

29. Johansson S, Irgens H, Chudasama KK, Molnes J, Aerts J, et al. Exome sequencing and genetic testing for MODY. PLoS One 2012;7:e38050.

30. Molven A, Njolstad PR. Role of molecular genetics in transforming diagnosis of diabetes mellitus. Expert Rev MolDiagn 2011;11:31320.

31. Froguel P, Vaxillaire M, Sun F, Velho G, Zouali H, Butel MO, Lesage S, Vionnet N, Clement K, Fougerousse F, et al. Close Linkage Of Glucokinase Locus On Chromosome $7 \mathrm{p}$ To Early-Onset Non-InsulinDependent Diabetes Mellitus. Nature 1992;356:162164.

32. Hattersley AT, Turner RC, Permutt MA, Patel P, Tanizawa Y, Chiu KC, O'Rahilly S, Watkins PJ, Wainscoat JS: Linkage Of Type 2 Diabetes To The 
Bhat JA; et al; Maturity-onset diabetes of the young (MODY): Recognition is the need of the hour

Glucokinase Gene. Lancet 1992:339:13071310.

33. Yamagata K, Furuta H, Oda N, Kalsaki PJ, Menzel S, Cox NJ, Fajans SS, Signorini S, Stoffel M, Bell G. Mutations In The Hepatocyte Nuclear Factor-4-Alpha Gene In Maturity-Onset Diabetes Of The Young (MODY1). Nature 1996;384:458-460.

34. Yamagata K, et al. Mutations In The Hepatocyte Nuclear Factor-1 alpha Gene In Maturity-Onset Diabetes Of The Young (MODY3). Nature 1996;384:455458.

35 Harries LW, Ellard S, Stride A, Morgan NG, Hattersley AT. Isomers of the TCF1 gene encoding hepatocyte nuclear factor-1alpha show differential expression in the pancreas and define the relationship between mutation position and clinical phenotype in monogenic diabetes. Hum Mol Genet 2006;15:2216-24.

36 Hattersley A, Bruining J, Shield J, Njolstad P, Donaghue K, International Society for Pediatric and Adolescent Diabetes, et al. ISPAD Clinical Practice Consensus Guidelines 20062007. The diagnosis and management of monogenic diabetes in children.Pediatr Diabetes 2006; 7:35260.

37 Stoffrs DA, Ferrer J, Clarke WL, Habener JF. Earlyonset type II diabetes mellitus (MODY4) linked to IPF1. Nat Genet 1997;17:138-9.

38 Schwitzgebel VM, Mamin A, Brun T, Ritz-Laser B, Zaiko M, Maret A, Jornayvaz FR, Theintz GE, Michielin O, Melloul D, Philippe J. Agenesis of human pancreas due to decreased half life of insulin promoter factor 1. J ClinEndocrinolMetab 2003;88:4398-406.

39 Horikawa Y, Iwasaki N, Hara M, Furuta H, Hinokio Y, Cockburn BN, Lindner T, Yamagata K, Ogata M, Tomonaga O, Kuroki H, Kasahara T, Iwamoto Y, Bell GI. Mutation in hepatocyte nuclear factor-1 beta gene (TCF2) associated with MODY. Nat Genet 1997;17:384-5.

40 Edghill EL, Bingham C, Slingerland AS, Minton JA, Noordam C, Ellard S, Hattersley AT. Hepatocyte nuclear factor-1 beta mutations cause neonatal diabetes and intrauterine growth retardation: support for a critical role of HNF-1beta in human pancreatic development. Diabet Med 2006;23:1301-6.

41 Bellanne-Chantelot C, Chauveau D, Gautier JF,
Dubois-Laforgue D, Clauin S, Beaufis S, Wilhelm JM, Boitard C, Noel LH, Velho G, Timsit J. Clinical spectrum associated with hepatocyte nuclear factor1beta mutations. Ann Intern Med 2004;140:510-7.

42 Malecki MT, Jhala US, Antonellis A, Fields L, Doria A, Orban T, Saad M, Warram JH, Montminy M, Krolewski AS. Mutations in NEUROD1 are associated with the development of type 2 diabetes mellitus. Nat Genet 1999;23:323-8.

43 Gonsorcikova L, Pruhova S, Cinek O, Ek J, Pelikanova T, Jorgensen T, Eiberg H, Pedersen O, Hansen T, Lebl J. Autosomal inheritance of diabetes in two families characterized by obesity and a novel H241Q mutation in NEUROD1. Pediatr Diabetes 2008;9:367-72.

44 Rubio-Cabezas O, Minton JA, Kantor I, Williams D, Ellard S, Hattersley AT. Homozygous mutations in NEUROD1 are responsible for a novel syndrome of permanent neonatal diabetes and neurological abnormalities. Diabetes 2010;59:2326-31.

45 Johansson BB, Torsvik J, Bjorkhaug L, Vesterhus M, Ragvin A, Tjora E, Fjeld K, Hoem D, Johansson S, Raeder H, Lindquist S, Hernell O, Cnop M, Saraste J, Flatmark T, Molven A, Njolstad PR. Diabetes and pancreatic exocrine dysfunction due to mutations in the carboxyl ester lipase gene-maturity onset diabetes of the young (CEL-MODY): a protein misfolding disease. J BiolChem 2011;286:34593-605

46 Bowman P, Flanagan SE, Edghill EL, Damhuis A, Shepherd MH, Paisey R, Hattersley AT, Ellard S. Heterozygous ABCC8 mutations are a cause of MODY. Diabetologia 2012;55:123-7.

47 Bonnefond A, Philippe J, Durand E, Dechaume A, Huyvaert M, Montagne L, Marre M, Balkau B, Fajardy I, Vambergue A, Vatin V, Delplanque J, Le Guilcher D, De Graeve F, Lecoeur C, Sand O, Vaxillaire M, Froguel P. Whole-exome sequencing and high throughput genotyping identified KCNJ11 as the thirteenth MODY gene. PLoS One 2012;7:e37423.

48 Shepherd M, Sparkes AC, Hattersley AT. Genetic testing in maturity onset diabetes of the young (MODY): a new challenge for the diabetic clinic. Pract Diabetes Int 2001;18:1621.

49 Rubio-Cabezas O, Hattersley AT, Njolstad PR, Clinical 
Bhat JA; et al; Maturity-onset diabetes of the young (MODY): Recognition is the need of the hour

Practice Consensus Guidelines ISPAD, et al. The diagnosis and management of monogenic diabetes in children and adolescents.Pediatr Diabetes 2014;15:4764.

50 Kavvoura FK, Owen KR. Maturity onset diabetes of the young: clinical characteristics, diagnosis and management. PediatrEndocrinol Rev 2012;10:234-42.

51 Ellard S, Lango Allen H, De Franco E, Flanagan SE, Hysenaj G, Colclough K, Houghton JA, Shepherd M, Hattersley AT, Weedon MN, Caswell R. Improved genetic testing for monogenic diabetes using targeted next-generation sequencing. Diabetologia 2013;56:1958-63.

52 Thanabalasingham G, Pal A, Selwood MP, Dudley C, Fisher K, Bingley PJ, Ellard S, Farmer AJ, McCarthy MI, Owen KR. Systematic assessment of etiology in adults with a clinical diagnosis of young-onset type 2 diabetes is a successful strategy for identifying maturity-onset diabetes of the young. Diabetes Care 2012;35:1206-12.

53 Shields BM, McDonald TJ, Ellard S, Campbell MJ, Hyde C, Hattersley AT. Th development and validation of a clinical prediction model to determine the probability of MODY in patients with young-onset diabetes. Diabetologia 2012;55:1265-72.

54 McDonald TJ, Shields BM, Lawry J, Owen KR, Gloyn AL, Ellard S, et al. High-sensitivity CRP discriminates HNF1A-MODY from other subtypes of diabetes. Diabetes Care 2011;34:18602.

55 Owen KR, Thanabalasingham G, James TJ, Karpe F, Farmer AJ, McCarthy MI, et al. Assessment of highsensitivity C-reactive protein levels as diagnostic discriminator of maturity-onset diabetes of the young due to HNF1A mutations. Diabetes Care 2010;33:191924.

56 Thanabalasingham G, Huffman JE, Kattla JJ, et al. Mutations in HNF1A result in marked alterations of plasma glycan profile. Diabetes 2013;62:132937.

57 Bacon S, Kyithar MP, Schmid J, et al. Circulating CD36 is reduced in HNF1A-MODY carriers. PLoS One. 2013 Sep 12.8(9):e74577.

58 Stride A, Shields B, Gill-Carey O, Chakera AJ, Colclough $\mathrm{K}$, et al. Cross-sectional and longitudinal studies suggest pharmacological treatment used in patients with glucokinase mutations does not alter glycaemia. Diabetologia 2014;57:546.

59 Hattersley A, Bruining J, Shield J, Njolstad P, DonaghueKC. The diagnosis and management of monogenic diabetes in children and adolescents.Pediatr Diabetes 2009; 10:3342.

60 Pearson ER, Starkey BJ, Powell RJ, Gribble FM, Clark PM, et al. Genetic cause of hyperglycaemia and response to treatment in diabetes. Lancet 2003;362:127581.

61 Pearson ER, Pruhova S, Tack CJ, Johansen A, Castleden HA, et al. Molecular genetics and phenotypic characteristics of MODY caused by hepatocyte nuclear factor 4-alpha mutations in a large European collection. Diabetologia 2005;48:87885.

62 Laver TW, Colclough K, Shepherd M, Patel K, Houghton JA, Dusatkova P, Pruhova S, Morris AD, Palmer CN, McCarthy MI, Ellard S, Hattersley AT, Weedon MN. The common p.R114W HNF4A mutation causes a distinct clinical subtype of monogenic diabetes. Diabetes 2016; 65:3212-7.

63 Fajans SS, Brown MB. Administration of sulfonylureas can increase glucose-induced insulin secretion for decades in patients with maturity-onset diabetes of the young. Diabetes Care 1993;16:125461.

64 Pearson ER, Pruhova S, Tack CJ, Johansen A, Castleden HA, et al. Molecular genetics and phenotypic characteristics of MODY caused by hepatocyte nuclear factor 4alpha mutations in a large European collection. Diabetologia 2005;48:87885.

65 Horikawa Y, Iwasaki N, Hara M, Furuta H, Hinokio Y, et al. Mutation in hepatocyte nuclear factor-1 beta gene (TCF2) associated with MODY. Nat Genet 1997;17:3845. 